\title{
Testing Environmental Kuznets Curve Hypothesis at Firm Level in India
}

\author{
Vinayagamoorthi Vasanth ${ }^{1}$, Murugesan Selvam ${ }^{1}$, Kasilingam Lingaraja ${ }^{1}$, Isaiah Onsarigo Miencha ${ }^{1} \&$ Mariappan \\ Raja $^{2}$ \\ ${ }^{1}$ Department of Commerce and Financial Studies, Bharathidasan University, Tiruchirappalli, India \\ ${ }^{2}$ Department of Commerce, Bharathidasan University Constituent College, Lalgudi, India \\ Correspondence: Vinayagamoorthi Vasanth, Department of Commerce and Financial Studies, Bharathidasan \\ University, Tiruchirappalli - 620024, India. E-mail: cavasanth@gmail.com
}

Received: August 3, 2015 Accepted: August 11, 2015 Online Published: September 27, 2015

doi:10.5539/jsd.v8n8p201 URL: http://dx.doi.org/10.5539/jsd.v8n8p201

\begin{abstract}
All over the world, deterioration of environmental quality has been considered as a hot issue. The growing number of industries is one of the major reasons for the enhanced level of pollution and fast degradation of environmental resources. This situation urges the corporates to involve themselves in socially responsible activities and to periodically assess the ecofriendly technologies. This paper proposes to investigate the Environmental Kuznets Curve Hypothesis, with reference to sample companies listed in BSE S\&P - 500, over the period $1^{\text {st }}$ April 2005 to $31^{\text {st }}$ March 2014. In order to determine the existence of EKC relationship, the sign and magnitude of regression coefficients were analyzed. The results exhibited $U$ shaped relationship for ROE, ROCE, and ROS. At the same time, EKC relationship, by way of inverted U shaped curve, was found for ROA. Based on the empirical findings of this study, some suggestions have been put forward to the corporates and policy makers, to control the level of energy intensity, by implementing eco-friendly technologies.
\end{abstract}

Keywords: energy intensity, Environmental Kuznets Curve (EKC), environmental performance, financial performance

\section{Introduction}

The economic development is an important factor for all countries, in creating and improving the standard of living of people and infrastructure facilities. Many researchers assert that apart from the physical and human capital, the Natural Capital is one of the foremost resources for the development and growth of the economy. Natural Capital is otherwise called as the environmental resources which constitute the main economic assets (Barbier, 2003). In the process of Liberalisation, Privatisation, and Globalisation (LPG), the number of industries has increased all over the world. It is true that industrialization, as a result of LPG, helped to some extend to solve the major economic problems in India by increasing the per capita income, increasing the trade volume, attracting foreign direct investment, generating employment opportunities for the people etc. But any transition in the country's economy also leads to increase in the level of pollution, $\mathrm{CO}_{2}$ emission, global warming, deforestation etc. (Kander \& Lindmark, 2004). These ecological issues were not considered as serious issues until the period of industrial revolution. But after the period of development in industrialization, the level of environment degradation is on the increase. In achieving the growth of industry and to fulfill the demand of the people, the firms have been transformed into mass production process (Kavzoglu, 2008; Wen \& Chen, 2008). The production process is mechanized and adoption of technologies depends on the consumption of energy and natural resources like power, oil and gas. The energy and natural resources are as one of the major elements of production. The biological and physical components of industrial production are mixed up with nature and create the environment problems (Dhami et al., 2013).

This situation warns the global community, especially the firms to initiate ethical and responsible activities. Some researchers including Vinayagamoorthi et al., (2012), Frankel \& Romer (1999) insist that the corporate managers need to consider the environmental issues while taking business decisions and need to involve more Research and Development (R\&D) projects for promoting the environmental performance. Some of the corporates felt that the use of environmental friendly technologies have become an additional capital burdens for the firms, particularly in the developing stage and questioned the benefits of contribution towards environmental 
protection activities (Walley \& Whitehead, 1994) However, some corporates rightly sensed the fact that enjoying huge level of profit by firms, without the attendant social responsibility, is immoral. Also, if there is no contribution by firms towards the environmental protection, the future profit-earning opportunity of the companies would get affected and they may cease to be sustainable (Trung \& Kumar, 2005; Roca, 2003; Porter $\&$ Van der Linde, 1995). The different behaviors of the corporates lead to the problem of disequilibrium on the part of companies in respect of their contribution towards the environmental protection. For this reason, it is necessary to maintain the equilibrium among the corporates towards the contribution in ethical activities. The regulatory authorities, corporate decision makers, investors and other stake holders of the company are keenly watching the contributions of companies toward the social responsible activities (Cormier \& Magnan, 2003; Stern, 1992). It is very important to understand the nature and relationship between environmental and economic development, before adopting a policy (Coondoo \& Dinda, 2002). In the last decades, the core theme of many researches is to examine the relations between the financial performance and environmental performance (Yang et al., 2015; Eroglu \& Hofer, 2014; Tiwari et al., 2013). But the study examining the corporate environmental performance is very few.

The present study looks beyond the relationship and examines the existence of Environmental Kuznets curve on the firm level environmental and financial performance in India. The result of this study helps to identify the shape of relationship between environmental and financial performance of the firms. Also, it suggested the place (turning point) where the change occurs in the behavior of corporates towards environmental / social responsibility. Likewise, the findings of this study would help the Socially Responsible Investors (SRI) to understand the social and ethical contribution of the companies. Further, the results of this study would help the policy makers to frame appropriate policy to persuade companies to implement green technology for optimal energy utilization for the production. Hence this research is considered as an important to increase the contribution by companies towards the implementation of ecofriendly technologies for energy savings.

\subsection{Environmental Kuznets Curve (EKC)}

Kuznets Curve is the graphical representation, based on the theory that during the time of economic development, the inequality of the income among people is also increasing. But after attaining a certain level of income, the inequality begins to decrease. This theory was first developed by the great economist and a noble prize winner, Simon Kuznets. Kuznets (1955) found the inverted-U-shaped relationship between per capita income and economic inequality. It explains that increase in per capita income leads to increase in economic inequality. But after the certain stage, increase in per capita income leads to decrease in economic equality. This relationship is represented by a bell shaped curve. This curve is popularly called as the Kuznets Curve.

The Kuznets Curve acquired a new dimension in the later stage of 1990s and onwards. The aspects of environmental degradation and the financial development were examined with the help of Kuznets Hypothesis. The study on the environmental degradation and income could be explained by the inverted-U shaped relationship between the level of environmental degradation and financial development. Grossman and Krueger (1993), Panayotou (1993), Shafik and Bandyopadhyay (1992) discussed the Environmental Kuznets Curve in their research papers. Grossman and Krueger (1993) found the inverted-U shaped relationship between pollution and economic development. Later, Kuznets Curve was extended as the Environmental Kuznets Curve to describe the relationship between environmental quality and income.

\subsection{Effects of Environmental Kuznets Curve (EKC)}

The economic development impacted the environmental performance in three forms such as Scale Effect, Composition Effect and Technique Effect. The Scale Effect explains that the degradation of environment is more during the stage of development of a country. This effect shows that more resources (input) are used in production process to increase the level of output. It explains that the involvement in environmental protection activities are improved only when the sufficient economic development had been achieved (Dinda, 2004; Borghesi, 2001). The Composition Effect explains the fact that the economic growth creates positive impact on environment. It explains that the degradation of environment is on the increase while there are changes in the structure of the economy (i.e., from agricultural to industrial, rural to urban). But the increasing trends of the environmental degradation start falling when another structural change takes place i.e., from energy intensive to service or knowledge based technology (Grossman \& Krueger, 1993). The Technique Effect represents that the economic development helps the emergence of a production process, re-invented with new and ecofriendly technology. The contribution towards the R\&D is possible only when the surplus funds are available and used for technology (Komen et al., 1997). 


\section{Review of Literature}

The relevant reviews, relating to the environmental performance and Kuznets Curve, are briefly discussed below to identify the research gaps, estimation techniques and managerial implications.

Georgiev and Mihaylov (2015) tested the hypothesis of Environmental Kuznets Curve in countries under the Organization for Economic Cooperation and Development (OECD), with income and air pollutants. The analysis found the existence of environmental Kuznets Curve, with inverted U- shaped relationship between income and pollution. Vasanth et al., (2015) identified the linear and causal relationship between the environmental performance and profitability of the firms in India. Vinayagamoorthi et al., (2015) examined the impact of financial performance on environmental performance of Indian firms and found that three variables, namely, ROA, ROE, and ROS showed significant positive impact but at the same time, one variable, namely, ROCE recorded negative impact on environmental performance of the sample firms in India. Yang et al., (2015) revisited the existence of Environmental Kuznets Curve in China. The study considered the economic performance and emission related indicators such as $\mathrm{CO}_{2}$ emission, $\mathrm{SO}_{2}$ emission, industrial waste etc. and could not find evidence of Environmental Kuznets Curve Hypothesis in China. Eroglu and Hofer (2014) investigated the U.S. manufacturing industries about the effect of environmental dynamism on the relationship between inventory leanness and financial performance. The innovative intensity, demand uncertainty and competitive intensity were used as proxy variables to measure the environmental dynamism of the firm. It is found that the innovative intensity helped to increase the effect of inventory leanness on firm performance. At the same time, the competitive intensity and demand uncertainty did not show significant effects. Zhao et al. (2014) examined the energy consumption and efficiency of the manufacturing industries in China and Japan. It is found that in the manufacturing industries of both countries, the level of energy intensity got significantly decreased. However, the structural changes improved the efficiency of the firm. Tiwari et al. (2013) made an attempt to examine the relationship between coal consumption, economic growth, trade openness and $\mathrm{CO}_{2}$ emissions in India and confirmed the existence of Environmental Kuznets Curve. Duarte et al. (2013) analysed the shape of the relationship between the income and water usage by using regression approach and identified inverted $U$ shape relationship between water usage and income level. Kanjilal and Ghosh (2013) tested the existence of Environmental Kuznets Curve and the relationship between macro level environmental variables and economic performance. This study considered the carbon emission, energy use, economic activity and trade openness in India during the period $1971-2008$. The result of this study identified the existence of Environmental Kuznets Curve in India and found the relationship between carbon emission and per capita income. The study by Saboori and Sulaiman (2013) denied the relevance of Environmental Kuznets Curve in Malaysia and found the bi-directional causal relationship between the economic growth and $\mathrm{CO}_{2}$ emission. Also, it is suggested that control over the energy consumption may hinder the economic growth. Sagala et al., (2013) tested the Environmental Kuznets Curve and relationship between urbanization and expenditure inequality in Indonesia. The panel data regression was used for the purpose of analysis and found that the result supported the Environmental Kuznets Curve. It is found that the inverted - U shape relationship did exist among the urbanization and expenditure inequality. Mythili and Mukherjee (2011) explored the relationship between river effluents and income of the Indian States. The analysis of this study ignored the existence of Environmental Kuznets Curve and indicated slanting-S shaped relationship. Earnhart and Lizal (2010) investigated the impact of firm level economic performance and environmental performance of Czech firms. The result found that performance of the firm distracted the performance of the firm level environment. Lopez Gamero et al., (2009) examined the relationship between environmental performance, environmental management and performance of the firm by considering the hotels and sample firms in Spain. This study identified that the environmental management system supported the improvement of environmental management and there was positive relationship between the environmental and firms' performance.

It is clear from the review of earlier studies that there was no comprehensive study in examining the existence of Environmental Kuznets Curve in the firm level environmental and financial performance, exclusively in India. The present study takes a step ahead to analyse the existence of Environmental Kuznets Curve in Indian firms.

\section{Conceptual Models, Estimation Techniques and Econometric Framework}

\subsection{Conceptual Models}

The present study examines the Environmental Kuznets Curve relationship between the environmental performance and financial performance of Indian firms. To test the appearance of curve, many econometric studies were carried out by using quadratic and cubic functions. Normally, these functions reveal the seven different forms of relationship (Kijima et al., 2010; Song et al., 2008; Dinda, 2004). This study also adopts the 
same quadratic and cubic function and framed four models as follows

$$
\begin{array}{lll}
Y=\beta_{1} \operatorname{ROA}_{+} \beta_{2} \operatorname{ROA}^{2}+\beta_{3} \operatorname{ROA}^{3} & ----- & \text { Model (1) } \\
Y=\beta_{1} \operatorname{ROE}_{+} \beta_{2} \operatorname{ROE}^{2}+\beta_{3} \operatorname{ROE}^{3} & ----- & \text { Model (2) } \\
Y=\beta_{1} \operatorname{ROCE}_{+} \beta_{2} \operatorname{ROCE}^{2}+\beta_{3} \operatorname{ROCE}^{3} & ----- & \text { Model (3) } \\
Y=\beta_{1} \operatorname{ROS}_{+} \beta_{2} \operatorname{ROS}^{2}+\beta_{3} \operatorname{ROS}^{3} & ------ & \text { Model (4) }
\end{array}
$$

The above models were administered to identify the different functional forms of relationship between environmental and financial performance of the sample firms and framed the null hypothesis as there is no Environmental Kuznets Curve (EKC) relationship between environmental performance and financial performance of Indian firms. Figure - 1 diagrammatically presents the various possible forms of relationship between environmental and financial performance. The line E represents the level of Environmental Pollution while the line Y represents Income / Economic Development (Mythili \& Mukherjee, 2011; Kijima et al., 2010; Akbostanci et al. 2009; Song et al., 2008).

(i) $\beta 1>0, \beta 2<0$ and $\beta 3>0$ reveals a cubic polynomial, representing a $\mathrm{N}$-shaped curve

(ii) $\beta 1<0, \beta 2>0$ and $\beta 3<0$ reveals a tilted $\mathrm{S}$ shaped relationship

(iii) $\beta 1<0, \beta 2>0$ and $\beta 3=0$ reveals a $U$ shaped relationship

(iv) $\beta 1>0, \beta 2<0$ and $\beta 3=0$ reveals an inverse U-shaped relationship, representing the $\mathrm{EKC}$

(v) $\beta 1>0$ and $\beta 2=\beta 3=0$ reveals a monotonically increasing linear relationship

(vi) $\beta 1<0$ and $\beta 2=\beta 3=0$ reveals a monotonically decreasing linear relationship

(vii) $\beta 1=\beta 2=\beta 3=0$ reveals a level relationship

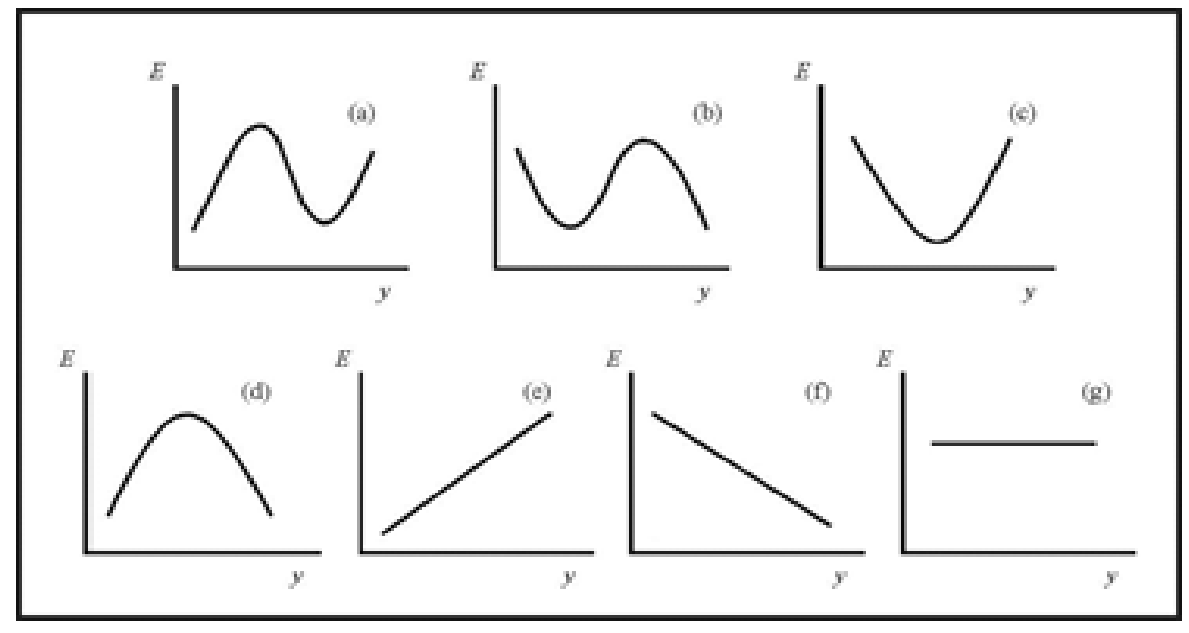

Figure 1. Various forms of Environmental Kuznets Curve (EKC)

Source: Developed by Song et al., (2008)

\subsection{Estimation Techniques and Econometric Framework}

It is normal to analyse the large companies in the major industries of the economy. In Bombay Stock Exchange of India, many indices are developed based on different criteria. Among the various indices, S\&P BSE-500 index reflects the changing pattern of the economy and it considers 500 companies from different major industries. Also this index covers $93 \%$ of the total market capitalization of Bombay Stock Exchange. Hence the 500 companies from S\&P BSE-500 index were considered for this study but the required data were available only for 191 companies. Hence the final sample size was fixed as 191 companies. The required data relating to Environmental Performance and Financial Performance for a period of 10 years from 1st April 2004 to 31st March 2014, were collected from the CMIE, PROWESS (online corporate database). The other required data were collected from reputed journals and websites.

In order to study the environmental performance of sample firms, parameters such as environmental efficiency score, adoption of ISO 14001, and ratio of toxic wastes were used (Horvathova, 2010). This study adopts the Energy Intensity as a proxy parameter for environmental performance (Vasanth et al., 2015; Vinayagamoorthi et 
al., 2015; Tung et al. 2014; Sahu \& Narayanan, 2011). To measure the financial performance of the sample firms, the present study considered the accounting based measures such as Return on Assets (ROA), Return on Equity (ROE), Return on Capital Employed (ROCE), and Return on Sales (ROS) (Qi, et al., 2014; Iwata \& Okada, 2011; Elsayed \& Paton, 2005; Hart \& Ahuja, 1996).

Further, to find out the existence of EKC relationship between environmental and financial performance, the magnitude of regression coefficient was used (Al-Mulali, et al., 2015; Eroglu \& Hofer, 2014; Ogundipe et al., 2014; Sagala et al., 2013; Brajer et al., 2011; Mythili and Mukherjee, 2011). For the parameters (b1, b2, and b3) of these models, homogeneity was assumed (Song et al., 2008). Further, this study applied Descriptive Statistics, and Correlation Coefficient to examine the nature and behavior of the variables and to examine environmental and financial performance of the sample firms in India.

\section{Empirical Results and Discussion}

\subsection{Analysis of the Nature of Environmental and Financial Performance variables}

The descriptive statistics describes the nature of environmental and financial performance related variables considered for this study. The descriptive statistics includes mean, standard deviation (SD), minimum, and maximum for the selected variables and the results are summarises in Table -1 .

It is to be noted that during the study period, the average value of energy intensity was recorded at 0.0459 (i.e., the value of energy consumption was only 4.59 percent of total sales value). Further, the value of standard deviation for energy intensity was 0.0124 . It indicates the fact that the mean value of energy intensity may increase / decrease by 1.24 percent over the value of sale. Minimum and maximum values of energy intensity were 0.0383 and 0.0800 respectively. During the study period, the range of energy intensity moved within the values of 3.83 percent (minimum value) and 8 percent (maximum value) in respect of sample firms.

According to the results of the Table, the mean value for ROA was 0.1231 percent with standard deviation value at 0.0405 . At the same time, minimum and maximum values for ROA were observed as 0.0938 and 0.2048 respectively. This indicates that the amount of profit was 12.31 percent of total assets of the sample firms. The result of standard deviation exhibits that the mean value of ROA may increase / decrease by 4.05 percent. Minimum and maximum values would help to identify the range of ROA during the study period. The analysis shows that the value of ROA of sample firms moved up and down, between the values of 0.2048 and 0.938 in respect of sample firms.

The results of descriptive statistics for ROE, depict the values of $0.233,0.0673,0.1613$, and 0.4009 for mean, standard deviation, minimum and maximum respectively. It implies that the during the study period, the sample firms enjoyed 23.30 percent of the value of equity as the profit. Also it is important to note that during the study period, the value of ROE of sample firms ranged from 0.1613 to 0.4009 . The result of standard deviation indicates that the mean value of ROE may increase or decrease around 6.73 percent in respect of sample firms.

From the Table, it is observed that during the study period, the mean value of ROCE was 0.1816 . It reveals that sample firms earned 23.30 percent of value of capital employed as the profit during the study period. Also the Table summarises the values of standard deviation, minimum, and maximum values at ROCE as $0.0673,0.1613$, and 0.4009 respectively. It indicates that the value of ROCE moved up or down between the values from 0.1320 ( $\mathrm{min}$ ) to $0.3193(\mathrm{max})$ during the study period. Further, 5.24 percent of variation in the mean value of ROCE was recorded for sample firms.

The results of summary statistics, clearly showed that the mean value of ROS was 0.1637 with the standard deviation value of 0.596 , for sample firms during the study period. It means that the sample firms earned 16.37 percent of sales as profit during the study period. According to the results of standard deviation, the mean value of sale may increase or decrease by 5.96 percent. Further, minimum and maximum values were 0.1021 and 0.2738 respectively in respect of sample firms. It indicates that the profit (in percent) of sample firms ranged from 10.21 percent to 27.38 percent of sales during the study period.

The results of the Table reveal that the value of energy consumption was only at moderate level (i.e., value of energy consumption was 4.59 percentage over the value of sales). This indicates that the sample firms controlled the level of energy intensity during the study period i.e., the mean value $(-0.0459)$ was only half of the maximum value (- 0.0800) of EI. In other words, during the study period, the environmental performance of sample firms increased by way of reducing the level of energy intensity. This clearly shows that there was effective energy consumption by the sample firms during the study period. At the same time, much difference was found in the value of energy intensity (maximum - 8 percent and minimum values -3.83 percent). Hence, it is inferred that the sample firms took appropriate steps and control over energy consumption. At the same time, 
the value of standard deviation for energy intensity reveals that the value of energy intensity was stable, with less variation (1.24 percent).

The results of summary statistics indicate that among the selected financial performance variables (ROA, ROE, ROCE, and ROS), the highest mean value (0.2330) was achieved by ROE while ROA recorded the lowest mean value of 0.1231 during the study period. Further, ROA showed a minimum value of 0.0938 , followed by ROS (0.1021), ROCE (0.1320), and ROE (0.1613). The maximum value was attained for ROE (0.4009) in respect of sample firms. It is to be noted that highest value of standard deviation (0.0673) was attained by ROE. It indicates that during the study period, ROE experienced more variation $(6.73$ percent $)$ from the mean value while the lowest value of standard deviation $(0.405)$ was earned by ROA during the study period.

Table 1. Results of descriptive statistics for environmental performance and financial performance related variables of sample firms from $1^{\text {st }}$ April 2005 to $31^{\text {st }}$ March 2014

\begin{tabular}{lclccc}
\hline Results & Energy Intensity & ROA & ROE & ROCE & ROS \\
\hline Mean & 0.0459 & 0.1231 & $\mathbf{0 . 2 3 3 0}$ & 0.1816 & 0.1637 \\
SD & 0.0124 & 0.0405 & $\mathbf{0 . 0 6 7 3}$ & 0.0524 & 0.0596 \\
Minimum & 0.0383 & $\mathbf{0 . 0 9 3 8}$ & 0.1613 & 0.1320 & 0.1021 \\
Maximum & 0.0800 & 0.2048 & $\mathbf{0 . 4 0 0 9}$ & 0.3193 & 0.2738 \\
\hline
\end{tabular}

Source: Compiled from Prowess and computed using SPSS - 20

Note: ROA - Return on Assets ROE - Return on Equity

ROCE - Return on Capital Employed ROS - Return on Sales

4.2 Analysis of Relationship between Environmental Performance and Financial Performance

Table 2. Result of correlation analysis for environmental performance and financial performance of sample firms during the study period of $1^{\text {st }}$ April 2005 to $31^{\text {st }}$ March 2014

\begin{tabular}{lccccc}
\hline \multicolumn{1}{c}{ Variables } & Energy Intensity & ROA & ROE & ROCE & ROS \\
\hline Energy Intensity & 1 & & & & \\
ROA & -0.029 & 1 & & & \\
ROE & $-0.131^{* *}$ & $0.231^{* *}$ & 1 & & \\
ROCE & $\mathbf{- 0 . 2 0 1 * *}$ & $0.284^{* *}$ & $\mathbf{0 . 8 4 5}^{* *}$ & 1 & \\
ROS & 0.016 & $\mathbf{0 . 6 6 2} 2^{* *}$ & $0.125^{* *}$ & $\mathbf{0 . 1 6 9 * *}$ & 1 \\
\hline
\end{tabular}

** Correlation is significant at the 0.01 level (2-tailed).

Source: Compiled from Prowess and computed using SPSS - 20

Note: ROA - Return on Assets ROE - Return on Equity

ROCE - Return on Capital Employed ROS - Return on Sales

Table - 2 elucidates the results of correlation analysis for environmental performance and financial performance related variables of the sample firms, during the period from $1^{\text {st }}$ April 2005 to $31^{\text {st }}$ March 2014. The correlation matrix displays the linear and interrelationship between environmental performance (EI) and financial performance - related variables (ROA, ROE, ROCE, and ROS). For the purpose of detailed analysis, the five sample variables were grouped into 10 sets of variables (EI - ROA, EI - ROE, EI - ROCE, EI - ROS, ROA ROE, ROA - ROCE, ROA - ROS, ROE - ROCE, ROE - ROS, and ROCE - ROS) to find the relationship between these sample variables. Out of 10 sets, four sets explains the linear relationship between environmental performance and financial performance of the sample firms during the study period and other six sets explain the interrelationship among the financial performance variables.

According to the correlation matrix, as showed at the Table, the value of correlation coefficient was -0.029 for energy intensity with ROA, -0.131 for energy intensity with ROE, -0.201 for energy intensity with ROCE, and 0.016 for energy intensity with ROS of sample firms during the study period. In other words, out of four profitability variables (ROA, ROE, ROCE, and ROS), only one profitability variable, namely ROS, recorded positive correlation (0.016) with energy intensity of the sample firms during the study period. But other three 
profitability variables such as ROA, ROE and ROCE were negatively correlated with energy intensity. More importantly, ROCE - EI experienced high negative correlation (-0.201) during the study period. Besides, the ROE - energy intensity (-0.131) and ROCE - energy intensity $(0.201)$ recorded significant value of correlation at $99 \%$ confidence level.

The Table also explains the interrelationship between financial performance variables during the study period. The value of correlation coefficient for ROA - energy intensity was 0.231 , ROE - energy intensity was 0.284 , and ROS - energy intensity was 0.662 . Further, two sets of variables, namely, ROE - ROCE, and ROE - ROS recorded the values of correlation at 0.845 and 0.662 respectively. Likewise, the ROCE - ROS earned the correlation coefficient value of 0.169 during the study period. It is understood that during the study period, all the four financial variables (ROA, ROE, ROCE, and ROS) were positively correlated with each other at $99 \%$ confidence level.

From the results of the Table, it is significant to note that the increase in values for ROA, ROE, and ROCE normally tended to decrease the value of energy intensity (i.e., in nature, the environmental performance variable and financial performance variables recorded inverse relationship and vice versa). At the same time, the financial variable, namely, ROS experienced direct relationship with energy intensity (i.e., increase in the value of ROS (by one unit) leads to increase in the value of energy intensity (by 0.16 unit) and vice versa). This establishes that the sample firms did take adequate measure to improve the environmental performance, along with the financial performance of the firms. The analysis of the Table shows that the increase in the values of ROA, ROE, and ROCE supported the improvement of the environmental performance of the sample firms during the study period. But one variable, namely, ROS leads to environmental degradation by increasing the level of energy intensity. Hence it is suggested $t$ hat for the environmental performance (to reduce the value of firm level energy intensity) in respect of sample firms, the corporate management should take appropriate steps to increase the level of income corresponding to the value of assets, equity and amount of capital employed by its effective utilization.

4.3 Analysis of Parameter Estimation for Linear, Quadratic and Cubic Models of Financial Performance Variables with Environmental Performance Variable

Table 3. Results of parameter estimation for linear, quadratic and cubic models of financial performance variables of sample firms

\begin{tabular}{|c|c|c|c|c|c|c|c|c|c|}
\hline \multicolumn{10}{|c|}{ 3.a) Model - I (ROA) } \\
\hline Results & b1 & b2 & b3 & Constant & R Square & F Statistics & P Value & Shape & $\begin{array}{c}\text { Turning } \\
\text { Point value }\end{array}$ \\
\hline Linear & 0.161 & - & - & 0.026 & 0.276 & 3.05 & 0.119 & \multirow{3}{*}{$\begin{array}{l}\text { Inverted U } \\
\text { shaped } \\
\text { relationship }\end{array}$} & \multirow{3}{*}{1.1978} \\
\hline Quadratic & 0.728 & -1.891 & - & -0.012 & 0.289 & 1.423 & 0.303 & & \\
\hline Cubic & 0.631 & 0 & -6.711 & -0.015 & 0.305 & 1.539 & 0.279 & & \\
\hline \multicolumn{10}{|c|}{ 3.b) Model - II (ROE) } \\
\hline Results & b1 & b2 & b3 & Constant & R Square & F Statistics & P Value & Shape & $\begin{array}{c}\text { Turning } \\
\text { Point value }\end{array}$ \\
\hline Linear & 0.141 & - & - & 0.013 & 0.58 & 11.069 & 0.01 & \multirow{3}{*}{$\begin{array}{c}\text { U shaped } \\
\text { relationship }\end{array}$} & \multirow{3}{*}{1.4059} \\
\hline Quadratic & -0.61 & 1.328 & - & 0.111 & 0.922 & 41.636 & 0.001 & & \\
\hline Cubic & 0 & -1.107 & 3.032 & 0.062 & 0.935 & 50.114 & 0.001 & & \\
\hline \multicolumn{10}{|c|}{ 3.c) Model - III (ROCE) } \\
\hline Results & b1 & b2 & b3 & Constant & R Square & F Statistics & P Value & Shape & $\begin{array}{c}\text { Turning } \\
\text { Point value }\end{array}$ \\
\hline Linear & 0.198 & - & - & 0.01 & 0.696 & 18.341 & 0.003 & \multirow{3}{*}{$\begin{array}{l}\text { U shaped } \\
\text { relationship }\end{array}$} & \multirow{3}{*}{1.3352} \\
\hline Quadratic & -0.738 & 2.038 & - & 0.108 & 0.931 & 47.14 & 0.001 & & \\
\hline Cubic & 0 & -1.677 & 5.825 & 0.061 & 0.934 & 49.883 & 0.001 & & \\
\hline \multicolumn{10}{|c|}{ 3.d) Model - IV (ROS) } \\
\hline Results & b1 & b2 & b3 & Constant & R Square & F Statistics & P Value & Shape & $\begin{array}{c}\text { Turning } \\
\text { Point value }\end{array}$ \\
\hline Linear & 0.107 & - & - & 0.028 & 0.264 & 2.864 & 0.129 & \multirow{3}{*}{$\begin{array}{l}\text { U shaped } \\
\text { relationship }\end{array}$} & \multirow{3}{*}{1.3243} \\
\hline Quadratic & -0.965 & 2.926 & - & 0.116 & 0.672 & 7.161 & 0.02 & & \\
\hline Cubic & 0 & -2.816 & 10.695 & 0.065 & 0.749 & 10.43 & 0.008 & & \\
\hline
\end{tabular}

Source: Compiled from Prowess and computed using SPSS - 20 
In this section, the existence of EKC and the possible shapes of relationship between environmental and financial performance variables was analyzed. For this purpose, the models such as ROA model (equation-1), ROE model (equation-2), ROCE model (equation-3), and ROS model (equation-4)] were tested and the results are summarized as linear function, quadratic function, and cubic function. As mentioned already, these results help to expose the seven different shapes of relationship such as monotonically increasing linear relationship, monotonically decreasing linear relationship, level relationship, $U$ shaped relationship, inverted $U$ shaped relationship (EKC), $\mathrm{N}$ shaped relationship and tilted $\mathrm{S}$ shaped relationship.

Table -3 shows the results of parameter estimation for linear, quadratic and cubic function of selected financial performance variables. In order to understand, the results are presented in 3.a, 3.b, 3.c, 3.d for Model - I (ROA), Model - II (ROE), Model - III (ROCE), Model - IV (ROS) respectively. The results of linear function for Model - I summaries that the coefficient value of ROA was 0.0161 while the constant value was 0.026 . At the same time, in quadratic function, the values of coefficient were 0.728 and -1.891 for ROA (b1) and ROA- squared (b2) respectively. Further, to identify the more possible shapes of relationship, the cubic function of ROA was used. According to the results of cubic function, the values of coefficient were 0.631 for ROA, 0.000 for ROA-squared, and -6.711 for ROA-cubed. From the results of the above functions, Model - I explicates an inverted U shaped relationship between energy intensity and ROA.

For Model -II (ROE), the estimated results of linear function shows the value of regression coefficient was 0.141 , with the constant value of 0.013 . Further the existence of EKC relationship was tested by using quadratic function. It is observed that the values of coefficient for ROE (b1) and ROE-squared (b2) were - 0.610 and 1.328 respectively. Also, result of cubic function shows the estimated coefficient values for ROE (b1), ROE-squared (b2), and ROE-cubed (b3) were $0.000,-1.107$, and 3.032 respectively in respect of sample firms. This results identified the $\mathrm{U}$ shaped relationship between ROE and energy intensity of the sample firms.

The value of coefficient for ROCE (b1) was 0.198 , with the constant value of 0.010 in the linear function of Model-III. The result of quadratic function expressed the value of parameter for ROCE (b1) was -0.738 while the value of ROCE - squared (b2) was 2.038. Likewise the Table summarizes the results of cubic function for Model -III. It shows the values of parameters were $0.000,-1.677$, and 5.825, for ROCE (b1), ROCE - squared (b2), and ROCE cubed (b3) respectively with the constant value at 0.061 . This results concluded that there was a U shaped relationship between the ROCE and energy intensity.

According to the Table, linear function of Model - IV shows the value of regression coefficient for ROS was 0.107 , along with the constant value at 0.028 . Also the magnitude of regression coefficient were -0.965 for ROS (b1), and 2.926 for ROS-squared (b2) of quadratic function. In order to estimate the more possible shapes of relationship, the cubic function was used for Model - IV. It resulted that the coefficient values for ROS, ROS-squared, and ROS-cubed were $0.000,-2.816$, and 10.695 respectively. This result indicates that the linear and cubic function does not explicit any shape of relationship between environmental and financial performance variables. But the coefficient values of quadratic function indicates a negative sign $(b 1<0)$ for ROS and positive sign $(b 2>0)$ for ROS-squared in respect of sample firms. In short, there was an existence of $U$ shaped relationship between EI and ROS in respect of sample firms.

The above discussed results indicate that there was an inverted U shaped (i.e., EKC) relationship between ROA and energy intensity. It explains that the consumption of energy was high during the increasing stage of ROA but after the value of turning point, the energy consumption was controlled. At the same time the other financial performance variables such as ROE, ROCE), ROS explicit U shaped relationship in respect of sample firms. The U shaped relationship explains that increase in the value of ROE, ROCE, and ROS supports for energy consumption until the value of turning point is reach. But after the value of turning point the ROE, ROCE, and ROS does not support for environmental performance.

In order to estimate the turning point, coefficient value of quadratic function was used. The turning point values for the above tested models were estimated by $-\mathrm{b} 1 / 2 \mathrm{~b} 2$ and constant value (Saboori \& Sulaiman, 2013; Song et al., 2008). Accordingly, the values of turning point for energy intensity were 1.978, 1.4059, 1.3352, and 1.3243 under model I, model II, model III, and model IV respectively. Further, the value of R square indicates the percentage of prediction of dependent variables by using tested models. The value of $F$ statistics and significance value explains that the results (quadratic functions) are significant at $95 \%$ confidence level for Models - II, Model - III, and Model - IV. But the result does not provide the significant results at $95 \%$ confidence level, for Model - I. To sum up, the three variables, namely, ROE, ROCE, and ROS manifested U-shaped relationship with energy intensity of the sample firms. Hence the null hypothesis that, there is no environmental Kuznets Curve (EKC) relationship between environmental performance and financial performance is accepted. 


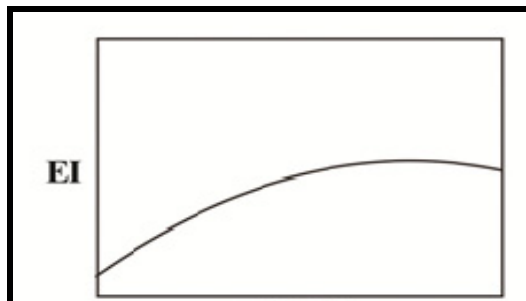

(2.a) ROA

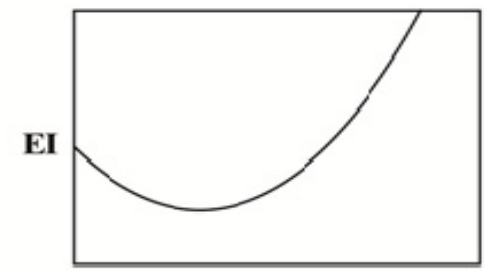

(2.e) ROCE

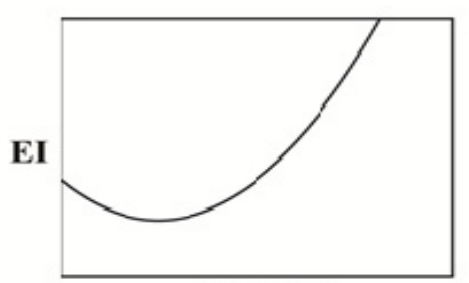

(2.b) ROE

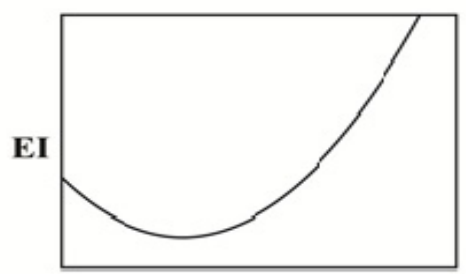

(2.d) ROS

Figure 2. Shape of relationship between environmental and financial performance variables

Source: Compiled from Table - 3 and computed using SPSS -20

The diagrammatical presentation of the shape of relationship between environmental and financial performance variables are presented in Figure 2. In the figure the scale of $\mathrm{Y}$ axis stands for the value of energy intensity and $\mathrm{X}$ axis represents the value of financial performance variables. Further the figure are classified on the basis of financial performance variables such 2.a, 2.b 2.c, and 2.d for ROA, ROE, ROCE, and ROS respectively. It explains inverted U shaped relationship for that the ROA with energy intensity (2.a), and U shaped relationship for ROE (2.b), ROCE (2.c), and ROS (2.d) with energy. The figure clearly shows that the value of energy intensity increases steadily along with the value of ROA. But after reaching a certain stage, the level of energy intensity was decreased in respect of sample firms. It is important to note that the figure exhibit that the value of energy intensity was in decreasing trend but after touching the value of turning the curve recorded an increasing trend while the value of ROE, ROCE, and ROS also increased correspondingly.

\section{Conclusion and Research Implications}

The present study examined the EKC relationship between environmental and financial performance variables such as ROA, ROE, ROCE, and ROS, by using extensive data, covering the period of $1^{\text {st }}$ April 2005 to $31^{\text {st }}$ March 2014. First, the results of the summary statistics show that among the selected financial performance variables, ROE performed well during the study period. Pandey (2010), Chandra (1997) mentioned that the value of ROE shows the profitability efficiency of firms over the value of equity. A higher value of ROE implies the effective productivity of the ownership capital. Also it indicates the effectiveness of the sample firm in utilizing its equity funds. Further, the results reveal that the value of energy consumption was at a moderate level. During the study period, the environmental performance increased without increasing the level of energy intensity. This indicates that the sample firms controlled the level of energy intensity during the study period. In other words, there was efficient consumption of energy by the sample firms. Secondly, the correlation matrix summaries the results of linear relationship between environmental and financial performance variables. It is important to note that three variables, namely, ROA, ROE, and ROCE did experience direct relationship with energy intensity while ROS recorded inverse relationship. Third, the estimation of EKC relationship shows that there was existence of EKC relationship between environmental and financial performance of the sample firms. In other words, there was a U shaped relationship for energy intensity with ROE, ROCE, and ROS while there was inverted $U$ shaped relationship with ROA. According to the result of turning points, the sample firms were presently at the developing stage. The result (no EKC relationship exist) of this study is consistent with the result of Mythili and Mukherjee (2011), Akbostanci et al. (2009). At the same time, the findings of this study contradict the results of Ahmed and Long (2012), Stern et al. (1996).

As pointed out by Panayotou (1997), there is a necessity for policy regulations to reduce the environmental degradation at low income level and improve environmental performance at higher income levels. Besides, it is urged that only corporates could initiate appropriate steps to control the level of energy consumption by 
implementing the eco-friendly technology. Also it is suggested to formulate appropriate policies to control environmental degradation by corporates and to increase the contribution towards the environmental protection activities.

Even though this study has many research implications, the results of this study was interpreted only on the basis of empirical analysis. However, some of limitations are inherent. In this study, the energy intensity was considered as the only variables to measure the environmental performance of the sample firms. This single measure may not produce the same results for the different environmental related variables. Further the results of this study relied only the data used in this study and estimation techniques. The criticisms of the Kuznets curve are also applicable to this study.

\section{References}

Ahmed, K., \& Long, W. (2012). Environmental Kuznets Curve and Pakistan: An Empirical Analysis. Procedia Economics and Finance, 1, 4-13. http://dx.doi.org/10.1016/S2212-5671(12)00003-2

Akbostanci, E., Turut-Asik, S., \& Tunc, G. I. (2009). The Relationship between income and environment in Turkey: Is there an environmental Kuznets curve? Energy Policy, 37, 861-867. http://dx.doi.org/10.1016/j.enpol.2008.09.088

Al-Mulali, U., Weng-Wai, C., Sheau-Ting, L., \& Mohammed, A. H. (2015). Investigating the environmental Kuznets curve (EKC) hypothesis by utilizing the ecological footprint as an indicator of environmental degradation. Ecological Indicators, 48, 315-323. http://dx.doi.org/10.1016/j.ecolind.2014.08.029

Barbier, E. B. (2003). The role of natural resources in economic development. Australian Economic Paper, 42(2), 253-272. http://dx.doi.org/10.1111/1467-8454.00198

Borghesi, S. (2001). The environmental Kuznets curve: a critical survey, In M. Franzini, \& A. Nicita (Eds.), Economic Institutions and Environmental Policy (pp. 201-224). Ashgate, Farnham, UK.

Brajer, V., Mead, R. W., \& Xiao, F. (2011). Searching for an environmental Kuznets curve in China's air pollution. China Economic Review, 22, 383-397. http://dx.doi.org/10.1016/j.chieco.2011.05.001

Chandra, P. (1997). Financial Management - Theory and Practice (4th ed.). Tata Mc Graw-Hill Publication Company Ltd. New Delhi.

Coondoo, D., \& Dinda, S., (2002). Causality between income and emission: a country group-specific $\begin{array}{lllll}\text { econometric } & \text { analysis. } & \text { Ecological 351-367. }\end{array}$ http://dx.doi.org/10.1016/S0921-8009(01)00280-4

Cormier, D., \& Magnan, M. (2003). Environmental Reporting Management: A European Perspective. Journal of Accounting and Public Policy, 22(1), 43-62. http://dx.doi.org/10.1016/S0278-4254(02)00085-6

Dhami, J. K., Singh, H., \& Gupta, M. (2013). Industrialization at the cost of environment degradation - a case of leather and iron and steel industry from Punjab economy. Innovative Journal of Business and Management, 2(1), 19-21.

Dinda, S. (2004). Environmental Kuznets curve hypothesis: a survey. Ecological Economics, 49(4), 431-455. http://dx.doi.org/10.1016/j.ecolecon.2004.02.011

Duarte, R., Pinilla, V., \& Serrano, A. (2013). Is there an environmental Kuznets curve for water use? A panel smooth transition regression approach. Economic Modelling, 38, 518-527. http://dx.doi.org/10.1016/j.econmod.2012.12.010

Earnhart, D., \& Lizal, L. (2010). Effect of corporate economic performance on firm level environmental performance in a transition economy. Environmental \& Resource Economics, 46, 303-329. http://dx.doi.org/10.1007/s10640-009-9342-0

Elsayed, K., \& Paton, D. (2005). The impact of environmental performance on firm performance: static and dynamic panel data evidence. Structural Change and Economic Dynamics, 16, 395-412. http://dx.doi.org/10.1016/j.strueco.2004.04.004

Eroglu, C., \& Hofer, C. (2014). The effect of environmental dynamism on returns to inventory leanness. Journal of Operations Management, 32, 347-356. http://dx.doi.org/10.1016/j.jom.2014.06.006

Frankel, J., \& Romer, D. (1999). Does trade cause growth?. American Economic Review, 89(3), 379-399. http://dx.doi.org/10.1257/aer.89.3.379

Georgiev, E., \& Mihaylov, E. (2015). Economic growth and the environment: reassessing the environmental Kuznets Curve for air pollution emissions in OECD countries. Letters in Spatial and Resource Sciences, 8, 


\section{9-47. http://dx.doi.org/10.1007/s12076-014-0114-2}

Grossman, G. M., \& Krueger, A. B. (1993). Environmental impacts of the North American Free Trade Agreement. In P. Garber (Ed.), The U.S. - Mexico Free Trade Agreement (pp. 13-56). MIT Press, Cambridge. Retrieved from http://www.nber.org/papers/w3914.pdf

Hart, S. L., \& Ahuja, G. (1996). Does it pay to be green? An empirical examination of the relationship between emission reduction and firm performance. Business Strategy and the Environment, 5, 30-37. http://dx.doi.org/10.1002/(SICI)1099-0836(199603)5:1<30::AID-BSE38>3.0.CO;2-Q

Horvathova, E. (2010). Does environmental performance affect financial performance? A meta - Analysis. Ecological Economics, 70, 52-59. http://dx.doi.org/10.1016/j.ecolecon.2010.04.004

Iwata, H., \& Okada, K. (2011). How does environmental performance affect financial performance? evidence from Japanese manufacturing firms. Ecological Economics, 70, 1691-1700. http://dx.doi.org/10.1016/j.ecolecon.2011.05.010

Kander, A., \& Lindmark, M. (2004). Energy consumption, pollutant emissions and growth in the long run: Sweden through 200 years. European Review of Economic History, 8, 297-335. http://dx.doi.org/10.1017/S1361491604001224

Kanjilal, K., \& Ghosh, S. (2013). Environmental Kuznet's curve for India: Evidence from tests for cointegration with unknown structural breaks. Energy Policy, 56, 509-515. http://dx.doi.org/10.1016/j.enpol.2013.01.015

Kavzoglu, T. (2008). Determination of environmental degradation due to urbanization and industrialization in Gebze, Turkey. Environmental Engineering Science, 25, 429-438. http://dx.doi.org/10.1089/ees.2006.0271

Kijima, M., Nishide, K., \& Ohyama, A. (2010). Economic models for the environmental Kuznets curve: a survey. Journal of Economic Dynamics and Control, 34(7), 1187-1201. http://dx.doi.org/10.1016/j.jedc.2010.03.010

Komen, M. H., Gerking, S., \& Folmer, H. (1997). Income and environmental R\&D: empirical evidence from OECD countries. Environment and Development Economics, 2(4), 505-515. http://dx.doi.org/10.1017/S1355770X97000272

Kuznets, P. (1955). Economic growth and income inequality. American Economic Review, 45, 1-28.

Lopez Gamero, M. D., Molina Azorin, J. F., \& Claver-Cortes, E. (2009). The whole relationship between environmental variables and firm performance: competitive advantage and firm resources as mediator variables. Journal of Environmental Management, 90(10), 3110-3121. http://dx.doi.org/10.1016/j.jenvman.2009.05.007

Mythili, G., \& Mukherjee, S. (2011). Examining Environmental Kuznets Curve for river effluents in India. Environment, Development and Sustainability, 13, 627-640. http://dx.doi.org/10.1007/s10668-010-9280-6

Ogundipe, A-A., Alege, P-O., \& Ogundipe, O-M. (2014). Income Heterogeneity and Environmental Kuznets

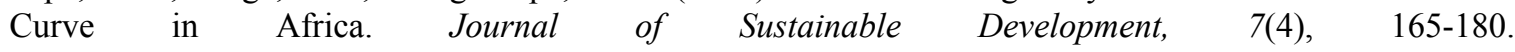
http://dx.doi.org/10.5539/jsd.v7n4p165

Panayotou, T. (1993), Empirical tests and Policy analysis of Environmental Degradation of different stages of economic development. Working paper WP238, Technology and Employment programme, Geneva: International labour Office. Retrieved from http://www.ilo.org/public/libdoc/ilo/1993/93B09_31_engl.pdf

Panayotou, T. (1997). Demystifying the environmental Kuznets curve: turning a black box into a policy tool. Environment and Development Economics, 2, 465-484. http://dx.doi.org/10.1017/S1355770X97000259

Pandey, I. M. (2010). Financial Management (10th ed.), Vikas Publishing House, New Delhi.

Porter, M., \& Van der Linde, C. (1995). Greeen and competitive: ending the stalemate. Harvard Business Review, $73,120-134$.

Qi, G. Y., Zeng, S. X., Shi, J. J., Meng, X. H., Lin, H., \& Yang, Q. X. (2014). Revisiting the relationship between environmental and financial performance in Chinese industry. Journal of Environmental Management, 145, 349-356. http://dx.doi.org/10.1016/j.jenvman.2014.07.010

Roca, J. (2003). Do individual preferences explain Environmental Kuznets Curve?. Ecological Economics, 45(1), 3-10. http://dx.doi.org/10.1016/S0921-8009(02)00263-X

Saboori, B., \& Sulaiman, J. (2013). Environmental degradation, economic growth and energy consumption: Evidence of the environmental Kuznets curve in Malaysia. Energy Policy, 60, 892-905. 
http://dx.doi.org/10.1016/j.enpol.2013.05.099

Sagala, P., Takahiro, A., \& Arief Anshori, Y. (2013). Urbanization and Expenditure Inequality in Indonesia: Testing the Kuznets Hypothesis with Provincial Panel Data. Letters in Spatial and Resource Sciences, 7, 133-147. http://dx.doi.org/10.1007/s12076-013-0106-7

Sahu, S. K., \& Narayanan, K. (2011). Determinants of energy intensity in Indian manufacturing industries: a firm level study. Eurasian Journal of Economics and Business, 4(8), 13-30.

Shafik, N., \& Bandyopadhyay, S. (1992). Economic Growth and Environmental Quality: Time Series and Cross-Country Evidence. Background Paper for the World Development Report, The World Bank, Washington, DC. Retrieved from http://www-wds.worldbank.org/servlet/WDSContentServer/WDSP/IB/1992/06/01/000009265_3961003013 329/Rendered/PDF/multi_page.pdf

Song, T., Zheng, T. G., \& Tong, L. J. (2008). An empirical test of the environmental Kuznets curve in China: a panel cointegration approach. China Economic Review, 19, 381-392. http://dx.doi.org/10.1016/j.chieco.2007.10.001

Stern, D. I., Common, M. S., \& Barbier, E. B. (1996). Economic Growth and Environmental Degradation: The Environmental Kuznets Curve and Sustainable Development. World Development, 24(7), 1151-1160. http://dx.doi.org/10.1016/0305-750X(96)00032-0

Stern, P. C. (1992). Psychological dimensions of global environmental change. Annual Review of Psychology, 43, 269-302. http://dx.doi.org/10.1146/annurev.ps.43.020192.001413

Tiwari, A-K., Shahbaz, M., \& Hye, Q-M. (2013). The environmental Kuznets curve and the role of coal consumption in India: Cointegration and causality analysis in an open economy. Renewable and Sustainable Energy Reviews, 18, 519-527. http://dx.doi.org/10.1016/j.rser.2012.10.031

Trung, D., \& Kumar, S. (2005). Resource use and waste management in Vietnam hotel industry. Journal of Cleaner Production, 13, 109-116. http://dx.doi.org/10.1016/j.jclepro.2003.12.014

Tung, A., Baird, K., \& Schoch, H. (2014). The relationship between organisational factors and the effectiveness of environmental management. Journal of Environmental Management, 144, 186-196. http://dx.doi.org/10.1016/j.jenvman.2014.05.025

Vasanth, V., Selvam, M., Lingaraja, K., \& Ramkumar, R.R. (2015). Nexus between Profitability and Environmental Performance of Indian Firms: An Analysis with Granger Causality. International Journal of Energy Economics and Policy, 5(2), 433-439.

Vinayagamoorthi, V., Murugasen, S., Kasilingam, L., Venkatraman, K., \& Mahalingam, G. (2012). Environmental management accounting - A decision making tools. International Journal of Management, 3(3), 144-151.

Vinayagamoorthi, V., Murugesan, S., \& Kasilingam, L. (2015). Impact of firms' profitability on environmental performance: evidence from companies in India. Mediterranean Journal of Social Sciences, 6(1), 109-119. http://dx.doi.org/10.5901/mjss.2015.v6n1p109

Walley, N., \& Whitehead, B. (1994). It's not easy being green. Harvard Business Review, 72, 46-52

Wen, Z., \& Chen, J. (2008). A cost-benefit analysis for the economic growth in China. Ecological Economics, 65, 356-366. http://dx.doi.org/10.1016/j.ecolecon.2007.07.007

Yang, H., He, J., \& Chen, S. (2015). The fragility of the Environmental Kuznets Curve: Revisiting the hypothesis with Chinese data via an "Extreme Bound Analysis", Ecological Economics, 109, 41-58. http://dx.doi.org/10.1016/j.ecolecon.2014.10.023

Zhao, Y., Ke, J., Ni, C. C., McNeil, M., Zheng Khanna, N., Zhou, N., Fridley, D., \& Li, Q. (2014). A comparative study of energy consumption and efficiency of Japanese and Chinese manufacturing industry, Energy Policy, 70, 45-56. http://dx.doi.org/10.1016/j.enpol.2014.02.034

\section{Copyrights}

Copyright for this article is retained by the author(s), with first publication rights granted to the journal.

This is an open-access article distributed under the terms and conditions of the Creative Commons Attribution license (http://creativecommons.org/licenses/by/3.0/). 